\author{
Mateusz Grześków* \\ ORCID: 0000-0003-1011-6413 \\ Jagiellonian University
}

DOI: $10.19195 / 1733-5779.29 .5$

\title{
The concept of the public company under Polish corporate law
}

\section{JEL Classification: K22}

Keywords: public company, listed company, private company, joint-stock company, capital markets, reform

Słowa kluczowe: spółka publiczna, spółka notowana, spółka prywatna, spółka akcyjna, rynek kapitałowy, reforma

Abstract: This paper is dedicated to the issue of the notion of the public company in Polish corporate law. This term, contrary to foreign legal systems, is detached from the fact of whether a given company's shares are listed on the stock exchange, as it is based solely on the technical aspect of whether shares are issued in dematerialized form. This approach should be deemed inappropriate. First of all, it blurs the distinction between a public company and a private company, as it does not at all address in substance the nature of listed companies. Secondly, it introduces into the legal system an obsolete category of public companies which are not equivalent to listed companies. Thirdly, the legislator wrongly adopts the private joint-stock company as the model joint-stock company in the Code of Commercial Companies (the "CCC") instead of its variant listed on the stock exchange. Consequently, a company which in practice has more in common with a limited liability company than with a listed company has been adopted as a model of a pure capital company. Due to these reasons it is the author's proposition to redefine the public and private company within the CCC and the capital markets regulation. This paper describes and positively assesses recent legislative proposals concerning the redefinition of the public company through linking its nature with the fact of its shares' admission to public trading.

\section{Koncepcja spółki publicznej w polskim prawie spółek}

Abstrakt: Niniejszy artykuł został poświęcony analizie ujęcia „spółki publicznej” w polskim prawie handlowym, które w odróżnieniu od systemów prawnych państw obcych oderwane jest od

* Scientific Tutor (Opiekun naukowy) — prof. dr hab. Andrzej Szumański 
faktu notowania akcji danej spółki na giełdzie papierów wartościowych, gdyż zostało oparte wyłącznie na technicznym aspekcie formy dokumentowej akcji. Ujęcie to należy uznać za błędne z kilku przyczyn. Po pierwsze, prowadzi ono to zatarcia granicy między spółką publiczną a spółką prywatną, ponieważ w ogóle nie odnosi się ono merytorycznie do specyfiki funkcjonowania spółek giełdowych. Po drugie, wprowadza do systemu prawnego zbędną kategorię spółek publicznych, która nie jest równoważna z kategorią spółek giełdowych. Po trzecie, ustawodawca błędnie przyjmuje, że modelową spółką akcyjną w kodeksie spółek handlowych jest jej podtyp niepubliczny w miejsce podtypu publicznego, przez co za wzorzec spółki kapitałowej przyjęto spółkę, którą w praktyce obrotu więcej łączy ze spółką z ograniczoną odpowiedzialnością niż ze spółką giełdową. Z tych względów postuluje się przedefiniowanie tych kategorii w obrębie kodeksu spółek handlowych oraz prawa rynku kapitałowego. Artykuł omawia oraz aprobuje wytyczony kierunek reformy prawa rynku kapitałowego, zgodnie z którym ma dojść do zredefiniowania pojęcia spółki publicznej przez powiązanie jej istoty $\mathrm{z}$ faktem dopuszczenia jej akcji do obrotu giełdowego.

\section{Initial remarks}

This article analyzes the concept of a public company under Polish corporate law. The notion of a public company is essentially of normative origin, because it is used across several regulations concerning the Polish capital market. Essentially, three major acts defining a public company should be indicated: the Code of Commercial Companies, ${ }^{1}$ the Act on Public Offer $^{2}$ and the Act on Trading in Financial Instruments. ${ }^{3}$ The first part of this paper is dedicated to the analysis of public company definition from a systematic perspective.

The next part of this article presents remarks regarding a model joint-stock company within the meaning of the CCC. The question raised is whether the public or the private company should serve as the model joint-stock company. Principally, it seems that the public company at its core has closer ties to what is typically associated with a joint-stock company rather than its private subtype. However, the Polish legislator determined otherwise, i.e., provisions regarding functioning of its public subtype are applied as a departure from the general rules, which stem from provisions on the private subtype. ${ }^{4}$

${ }^{1}$ Act dated 15 September 2000 - Code of Commercial Companies (Journal of Laws 2000 no. 94 item 1037, as amended), hereinafter referred to as "the CCC."

2 Act dated 29 July 2005 - on Public Offer and the Conditions for Introducing Financial Instruments to the Organized Trading System and Public Companies (Journal of Laws 2005 no. 184, item 1539 , as amended), hereinafter referred to as "the APO."

3 Act dated 29 July 2005 - on Trading in Financial Instruments (Journal of Laws 2005 no. 183, item 1538, as amended), hereinafter referred to as "the ATFI."

4 A. Opalski, [in:] Kodeks spótek handlowych, vol. 3A. Spótka akcyjna. Komentarz do art. 301-392, ed. A. Opalski, Warszawa 2016, commentary to the Article 4 of the CCC, side no. 38; A. Szumański, [in:] Kodeks spótek handlowych. Komentarz do art. 1-150, vol. 1, eds. S. Sołtysiński, A. Szajkowski, A. Szumański, Warszawa 2012, commentary to the Article 4 of the CCC, side no. 44-45. 
Finally, recent legislative amendments to the CCC, the APO and the ATFI are put under scrutiny, as they set forth a new definition of public company and reshape the legislator's stance toward this type of company. To some extent it may be viewed as a revolutionary change, as the definition of the public company remained stable and barely unchanged throughout years since the coming into force of the APO in 2005. A review of these changes along with their consequences is presented in the final part of this article.

\section{Definition of a public and private company under Polish law}

As mentioned in the introduction, the term "public company" is of normative origin under Polish law i.e., this term stems from statutory provisions rather than legal doctrine or case law. On the other hand, the notion of the private company was adopted by legal commentators based on features traditionally associated with closed companies whose shareholding structure is limited in numbers. The former term tends also to be associated more with partnerships (spótki osobowe ${ }^{5}$ ) than capital companies (spótki kapitatowe ${ }^{6}$ ), as typically partnerships are governed by persons who incorporated them, while capital companies are strictly tied to capital contributed by their shareholders. Thus, in partnerships, the voting power of each partner remains at the same level and the overall rights and duties in the enterprise are assigned separately to each partner. Decisions are taken unanimously by the partners, provided that they did not resolve otherwise in the partnership's deed. The internal structure of a partnership is scarce, as typically no bodies are established therein. The partners can be held liable for debts of partnership if it turns out to be insolvent. To capital companies these principles are not applicable as therein voting power remains closely tied with shares. Typically, resolutions are adopted by majority votes (or in other words, by a majority of

5 The Polish CCC distinguishes four types of partnerships: general partnership (spótka jawna), professional partnership (spótka partnerska), limited partnership (spótka komandytowa) and limited joint-stock partnership (spótka komandytowo-akcyjna).

${ }^{6}$ Only two types exists within frames of the CCC: limited liability company (spótka z ograniczona odpowiedzialnościa) and joint-stock company (in Polish — spółka akcyjna). Currently legislative works are undertaken aiming to introduce a third type, i.e. simplified joint-stock company (in Polish — prosta spótka akcyjna). It is not subject of further interest herein. See M. Grześkow, "Rozważania nad kształtem prostej spółki akcyjnej (PSA)," Internetowy Przeglad Prawniczy TBSP UJ2017, no. 10, pp. 17-39, http:// www.tbsp.wpia.uj.edu.pl/documents/4137545/140073332/IPP_10_2017.pdf/1af5e322-ebf0-4478-baae0a6aded86272; P.M. Wiórek, "O braku potrzeby wprowadzenia prostej spółki akcyjnej (PSA) z perspektywy prawnoporównaczej," Przegląd Prawa Handlowego 2018, no. 5, pp. 4-9; A. Kappes, "Prosta spółka akcyjna - czy rzeczywiście prosta i czy potrzebna? Uwagi do projektu nowelizacji Kodeksu spółek handlowych, wprowadzającego prostą spółkę akcyjną (projektowane art. $300^{1}-300^{121}$ k.s.h.)," Przegląd Prawa Handlowego 2018, no. 5, pp. 10-16; T. Sójka, "O potrzebie zmian unormowań niepublicznych spółek kapitałowych — uwagi na kanwie projektu przepisów o prostej spółce akcyjnej," Przegląd Prawa Handlowego 2018, no. 9, pp. 12-18. 
the capital represented by certain shares). Every capital company acts through its mandatory, internal bodies, as its legal personhood is separated from its shareholders, and thus acts in its own name. Consequently, shareholders can never be held liable for their debts. Due to these reasons, legal commentators distinguished the following principles: "rules of the majority over the minority" (zasada rzadów większości nad mniejszościa), "primacy of capital over person" (zasada prymatu kapitatu nad osoba) and "separation of capital from management" (rozdziat kapitalu od zarzadzania $)^{7}$ which are only attributable to capital companies and basically constitute their essence.

Essentially, a partnership is based on trust between its partners, which determines its closed (private) nature. In theory, a pure capital company is absolutely deprived of any personal features and is totally governed by capital. In other words, the higher the capital contribution to a capital company, the greater voting power there is.

Predominantly, the CCC does not define what should be regarded as a public company despite many of its provisions being dedicated to the functioning of a public company. Article 4(1)(6) of the CCC refers in this respect to the definition set forth in Article 4(20) of the APO which provides that a public company means a company in which at least one share has been dematerialized in the meaning of provisions of the ATFI. ${ }^{8}$ Finally, Articles 5 and 7 of the ATFI regulate the procedure of dematerializing shares, creation and transfer of rights attached to such shares. One should notice this relatively important term from the perspective of the CCC has been defined in fact through two separate, but still closely connected acts. It is very noticeable that currently the phenomenon of the public company is based only on a technical act being the dematerialization of shares i.e., their registration within a central securities depository. ${ }^{9}$ A significant consequence of this approach toward a public company is that its status is derived from the fact whether such a company is a listed company. ${ }^{10}$ However, typically attaining the status of a non-listed public company is in practice rather temporal, as subsequently such companies are submitting a motion to the Warsaw Stock Exchange on admitting their shares to public trading. Additionally, in order to attain the status of a listed company, such a company does not have to dematerialize all its

${ }^{7}$ S. Włodyka, A. Szumański, [in:] System Prawa Handlowego, vol. 2A. Prawo spótek handlowych, d. A. Szumański, Warszawa 2019, pp. 41-46.

${ }^{8}$ With exception to company whose shares are registered by virtue of Article 5a(2) of the ATFI. This minor exception is not subject of further analysis herein.

${ }^{9}$ In light of Article 3(21) of the ATFI, in Poland only Krajowy Depozyt Papierów Wartościowych S.A (the "Central Securities Deposit for Poland") may serve function of central securities depository. It is debatable whether a EU-CSD (i.e. non-Polish) may operate in Poland. See A. Famirski, [in:] Ustawa o obligacjach. Komentarz, ed. M. Wierzbowski, Warszawa 2019, pp. 40-42.

${ }^{10}$ M. Romanowski, "W sprawie pojęcia i natury spółki publicznej," Przegląd Prawa Handlowego 2009, no. 3, p. 13 . 
shares. By virtue of Article 5(1)(2) and 5(1)(3) of the ATFI, only shares admitted to trading on the regulated market or introduced into trading on the multilateral trading platform must previously be dematerialized. ${ }^{11}$ The rest of the shares may remain in documentary form, which occurs quite often in practice, as it is the only way to maintain privileges resulting from the taken-up registered shares.

As a result, the definition of a public company is based solely on technical criteria, while the nature of the public company remains utterly irrelevant from this perspective. In fact, this definition is restricted only to one of the methods of trading shares. It leads to a situation in which a non-listed company may attain the status of a public company and therefore fall under certain duties reserved in theory only for listed companies, even if few of its shares are dematerialized, and it does not intend at all to become a fully-fledged listed company.

Besides, it should be noted that under the ATFI not only joint-stock companies may achieve the status of s public company. Any company issuing shares in the meaning of the CCC is authorized to do so, therefore also the limited joint-stock company and the European company (SE) may register their shares within the Central Securities Deposit for Poland and in the end become public companies. ${ }^{12}$

\section{Listed company versus public company under Polish capital markets law}

Typically, public companies are associated with listed companies in everyday language or in foreign legal commentaries. ${ }^{13}$ In practice, the difference between these terms is a source of severe misunderstandings in contacts with non-Polish lawyers or clients, as obviously they are not familiar with reasoning behind telling apart these terms and to what extent they differ, as they are considered to be synonymous.

The notion of a listed company, like that of a private company, does not have a normative origin, ${ }^{14}$ nevertheless it is derived from descriptive terms such as: "a company whose shares have been admitted to the trading on a regulated market" 15 or "a company whose shares have been introduced into trading on a multilateral trading platform). ${ }^{16}$ Besides, the term of "a company whose shares can be admitted to the

${ }^{11}$ M. Michalski, [in:] Ustawa o obrocie instrumentami finansowymi. Komentarz, eds. M. Wierzbowski, L. Sobolewski, P. Wajda, Warszawa 2018, pp. 572-573.

12 A. Opalski, op. cit., commentary to the Article 4 of the CCC, side no. 37; A. Szumański, op. cit., commentary to the Article 4 of the CCC, side no. 48.

13 A. Chłopecki, "Regulacje spółki publicznej a kodeks spółek handlowych," Przegląd Prawa Handlowego 2015, no. 4, pp. 55-56.

${ }^{14}$ A. Akimenkow, "Spółka giełdowa a spółka publiczna — podstawy normatywne dystynkcji oraz koncepcje reformy nominałowej kapitału zakładowego," Przeglad Prawa Handlowego 2018, no. 9 , p. 55.

15 Ex.: Article 56(1) of the APO.

${ }^{16}$ Ex.: Article 75(3)(1) of the APO. 
official market" can be found as well. ${ }^{17}$ These terms are associated with the fact that shares of a given company are the subject of trading at a stock exchange, therefore it is necessary to submit some of its operational aspects to the public-regulation of capital markets. Most of these regulations are aimed at protecting minority investors' interests. ${ }^{18}$ Therefore, in my opinion in order to simplify the definition of a listed company, it should be understood as a company whose shares have been admitted to trading on the organized market in the meaning of Article 3(9) of the ATFI. ${ }^{19}$

Additionally, a fact easily noticeable in comparison between a listed and private company, is that the term "minority shareholder" tends to be replaced with "investor," as from the economic point of view it seems to be more suitable to their factual position in a company and reasons why they decided to invest their capital into a listed company. ${ }^{20}$ In the case of a private company, the minority shareholders, despite their low capital engagement, tend to actively participate in the company's affairs and cooperate with each other in order to protect their economic interests, as they possess limited options of disposing of their shares, therefore they cannot simply exit from the company if they do not agree with its current policy. In the case of public companies such a stance typically may be attributed to minority shareholders who are professional investors (usually investment funds), but most investors do not participate at all in the affairs of a public company, as their capital engagement is to that extent low, that the costs of such actions (in particular attending general meetings or challenging resolutions adopted thereby) are higher than the value of their investment. Due to the high liquidity of public companies' shares, such investors can easily exit their investment at any time. Also, such investors do not have time or effective tools to communicate with the others. Overall, a typical minority shareholder (investor) in a listed company is solely interested in gaining profits from regularly paid dividends and a potential increase of the value of shares. Several investors are simply speculators who acquire shares for a short period of time, therefore they are totally uninterested in its internal affairs. ${ }^{21}$

The majority of provisions concerning operation of a public company are provided by the $\mathrm{CCC}$ and barely any others can be found in the capital markets regulations. ${ }^{22}$ This is implied by the fact that the CCC regulates corporate aspects

${ }^{17}$ Such notion exists only in Article 56(2)(a) of the APO.

18 M. Spyra, [in:] System Prawa Handlowego, vol. 4. Prawo instrumentów finansowych, ed. M. Stec, Warszawa 2016, pp. 38-41.

19 According to this article, an organized market means trading securities or other financial instruments in Poland on the regulated market or multilateral trading platform.

${ }^{20}$ M. Michalski, "O pojęciu i zakresie regulacji spółki publicznej,” Przegląd Prawa Handlowego 2008, no. 1, pp. 6-7.

21 K. Oplustil, Instrumenty nadzoru korporacyjnego (corporate governance) w spótce akcyjnej, Warszawa 2010, pp. 128-147.

22 Notably, the squeeze-out and sell-out procedure are, respectively, regulated for private company in the Articles 418 and $418^{1}$ of the CCC and for public company in the Articles 82 and 83 of 
of the functioning of a joint-stock company as this is an act within private law, while the APO and the ATFI provide primarily public law duties of listed companies. $^{23}$ The latter contain mostly rules pertaining to: (i) the particulars of the public offering of shares and the procedure for approval of a prospectus, (ii) information disclosure duties regarding current and periodic reports, (iii) notification on the percentage of shares held, (iv) takeover bids, and (v) delisting of a public company. Obviously, these do not have much in common with corporate aspects of a joint-stock company's functioning set forth in the CCC which concerns several, usually unrelated to issues, such as inter alia acquisition of one's own shares, an increase in share capital, convening and organization of a general meeting, or merger procedure of companies. A public company must follow these departures from general rules on the operation of a private company, i.e., such a company may not decide to follow in certain aspects rules set forth for a private company and for public companies in others. Clearly, the legislator has divided the concept of a joint-stock company, in the CCC, into two separate types: private company and public company ${ }^{24}$. Overall, the legislator has adopted the view that a private company serves as a model company for the CCC.

As it seems in the light of the above, the distinction between a public company and a listed company is based on different criteria. However, it is obvious that regulation for a public company was prepared in such a way as to adjust its operational frames to the nature of a listed company. Nevertheless, this still does not address the question presented in the introduction of this paper.

\section{Model joint-stock company from the perspective of corporate law - remarks}

Notably, commercial companies within the CCC were developed in a way that a general partnership is deemed to be the pure, model type of partnership and joint-stock company represents a model capital company. ${ }^{25}$ The remaining types of commercial companies are to some extent regarded as a hybrid type of companies, i.e., they deviate from their basic model through the introduction of elements

the APO. Only in public company may be appointed expert witness for special purposes by virtue of resolution of the company's general meeting or eventually by the registry court's ruling. Such possibility is not envisaged for private company, according to the Article 84-86 of the APO.

${ }^{23}$ Duties regarding disclosure of inside information since entrance into force of Regulations (EU) 596/2014, of the European Parliament and of the Council of 16 April 2014 on market abuse (market abuse regulation) and repealing Directive 2003/6/EC of the European Parliament and of the Council and Commission Directives 2003/124/EC, 2003/125/EC and 2004/72/EC, are not anymore provided by the Polish regulations.

${ }^{24}$ A. Chłopecki, op. cit., p. 55.

${ }^{25}$ A. Szajkowski, [in:] System Prawa Prywatnego, vol. 16, ed. A. Szajkowski, Warszawa 2016, pp. 50-52; S. Sołtysiński, P. Moskwa, [in:] System Prawa Prywatnego, vol. 17A, ed. S. Sołtysiński, Warszawa 2015, pp. 3-5. 
not traditionally associated with their model (ex. establishment of bodies in a professional partnership or individual right of limited liability company's shareholders to control that company). ${ }^{26}$ Therefore, respective types of commercial companies should be described as having a dominant partnership or capital component supplemented by selected features of the other. Bearing this in mind, the following question should be asked: which type of joint-stock company should serve as a model jointstock company under the CCC - a private (non-public) or listed model (public)?

In order to answer the question posed above, a brief description of the theoretical concept and legal frames underlying a joint-stock company must be discussed. Predominantly, a joint-stock company as a capital company is a typical corporation whose main purpose is to raise capital required for its activity from either anonymous investors or large numbers of investors. A joint-stock company should be viewed as a vehicle within a legal framework which enables its creators to run their enterprise in a form which facilities raising capital for a common goal. These investors decide to cooperate with each other through the intermediary of a capital company, as separately none of them would be able to achieve their goals, as individually they do not own enough amount of property required thereto. ${ }^{27}$ Therefore, each shareholder (investor) is granted the same rights proportionally to the contributed capital. It is assumed that shareholders are not liable for the debts of a joint-stock company as it possesses a separate legal personhood from its shareholders, and that it should be professionally managed by competent representative who does not favor any shareholder and acts in the best interests of the company instead. These officers may be recruited amongst the ranks of shareholders or, preferably, from non-affiliated persons. Typically, shareholders participate in profits generated by a joint-stock company proportionally to the number of shares taken up by them. No privileges may be introduced to such a company, as every shareholder should be treated equally under the same circumstances (such a rule is provided in Article 20 of the CCC). ${ }^{28}$ In order to ensure these requirements, a principle "one share - one vote" should be adopted, ${ }^{29}$ the company should operate in a manner with transparent corporate governance rules and its statutes should be precisely regulated by applicable law.

A joint-stock company may at any time raise its capital through issuance of new shares to existing shareholders or potentially new investors. As the most important corporate act, it is the statutes which define internal relations between them, consequently any new entering (major) investor wishes to appropriately

${ }^{26}$ S. Włodyka, A. Szumański, op. cit., pp. 48-50.

27 J. Frąckowiak et al., [in:] System Prawa Handlowego, vol. 2B. Prawo spótek handlowych, ed. A. Szumański, Warszawa 2019, pp. 53-61.

${ }^{28}$ M. Romanowski, op. cit., pp. 11-13.

${ }^{29}$ T. Regucki, Mechanizmy zwiększające kontrolę (control enhancing mechanisms) w polskich spótkach akcyjnych. Analiza prawno-ekonomiczna, Warszawa 2018, pp. 21-30. 
redefine its provisions in order to protect his interests as well. However, not every investor wishes to remain active during his capital engagement into a joint-stock company due to the reasons presented earlier. Without doubt, such a stance should be regarded as their privilege and they cannot be denied the right to remain a passive investor. Consequently, what in my opinion strongly distinguishes private from public company is this element. In the case of a private company, the investor tends to be at least somehow engaged in the operations of the company as otherwise he is not able to protect his investment from potential abuses or frauds committed by the remaining shareholders. Another important aspect of the joint-stock company is the possibility to relatively easily transfer shares between shareholders and potential investors. A public company's shares should be, by definition, liquid enough to allow their shareholders to easily exit the investment at an earlier pre-determined price. In the case of a private company, the transfer of shares may be restricted not only by virtue of law or provisions of its articles of associations (while a public company cannot issue shares with restricted transferability). Quite often, such a possibility is severely restricted due to the lack of potential buyers (as transactions are conducted outside of the organized market) and the problem of determining a fair price for the stock. These issues typically do not occur at stock exchanges, where private companies are, obviously, not present, save for very rare exceptions usually linked to economic crises. Also, one last factor cannot be overlooked, in the case of a private company, typically all its shareholders know each other and have some relations between one another. In contrary, it cannot be attributed to a public company, as any entity can freely enter and exit it at will. Finally, an important feature of a joint-stock company is transparent and non-discriminatory informational policy towards its shareholders. Such a company should operate in a way which is able to instantly and publicly disclose any relevant information regarding its business, preferably on its internet website.

Based on the issues discussed above, the following conclusions can be drawn. A public (listed) joint-stock company should serve as the model joint-stock company in the CCC, instead of a private joint-stock company which, in practice, usually resembles a limited liability company more than a public joint-stock company. Its provisions should be constructed for that purpose, while certain deviations or simplifications should be provided in case of the private model. A private joint-stock company should be a subtype of a model joint-stock company. However, the legislator determined otherwise. This approach may be viewed as justified from a systematic point of view, as the CCC contains only provisions of a private character and no public regulations referring to the operation of listed companies are present herein. For this reason, all such norms were moved to other acts, mainly the APO and the ATFI. 


\section{Proposed legislative amendments - a review}

Currently, an amendment to the APO and certain other laws ${ }^{30}$ is the subject of legislative work. Its main purpose is to adjust these acts to the provisions of the Prospectus Regulation ${ }^{31}$ and implement any new institutions into the Polish capital markets law resulting from Directive (EU) 2017/828. ${ }^{32}$ Besides, other unrelated amendments are proposed, with the redefinition of the notion of a public company among them. Irrespective of the previously mentioned amendment also another amendment to the $\mathrm{CCC}^{33}$ is in progress, whose main purpose is to eliminate the documentary form of shares from the market through mandatory dematerialization of shares in limited joint-stock companies and joint-stock companies. According to the reasoning behind this amendment, a new type of shares called "registered share" (akcja rejestrowa) should be introduced into Polish law and subsequently, the deletion of the division of shares into bearer shares (akcje na okaziciela) and registered shares (akcje imienne) is proposed. ${ }^{34}$ This overhaul of the form of shares inevitably requires that the notion of public company be revised as well. Overall, both amendments aim independently from each other to redefine this term.

Essentially, its definition finally departs from the criterion of dematerialization of shares, as proposed by several legal commentators. ${ }^{35}$ No longer is this technical aspect of issuing shares of a company for public trading, considered relevant for the purposes of this definition. A public company is defined as a company whose shares are either admitted to trading on the regulated market or introduced into trading on the multilateral trading platform. Consequently, a public company is no longer distinguished from a listed company, as both terms are to be merged into one. This change must be welcomed with open arms, nevertheless its practical consequences should be presented.

${ }^{30}$ Project dated 23 May 2019 on the amendment of the Act on Public Offer and the Conditions for Introducing Financial Instruments to the Organized Trading System and Public Companies, and certain other acts. Available under (only in Polish): https:/legislacja.rcl.gov.pl/projekt/12318000/ katalog/12549094\#12549094 (accessed: 12.06.2019), hereinafter referred to as the "Amendment to the APO."

${ }^{31}$ Regulation (EU) 2017/1129 of the European Parliament and of the Council of 14 June 2017 on the prospectus to be published when securities are offered to the public or admitted to trading on a regulated market, and repealing Directive 2003/71/EC.

32 Directive (EU) 2017/828 of the European Parliament and of the Council of 17 May 2017 amending Directive 2007/36/EC as regards the encouragement of long-term shareholder engagement.

33 Project dated 22 May 2019 on the amendment of the Code of Commercial Companies and certain other acts. Available under (only in Polish): https:/legislacja.rcl.gov.pl/projekt/12294656/ katalog/12410433\#12410433 (accessed: 12.06.2019), hereinafter referred to as the "Amendment to the CCC."

34 Amendment to the CCC, p. 9.

${ }^{35}$ M. Romanowski, op. cit., pp. 15-16; A. Chłopecki, op. cit., p. 58. 
A joint-stock company attains the status of public company at the moment when it becomes a listed company, and with that moment it is obliged to fulfill duties set forth by the APO and other relevant acts. Accordingly, the wording of several provisions needs to be adjusted to the new, amended definition. Therefore, it is necessary to precisely indicate when that moment occurs. Overall, the ongoing public procedure is not regulated by any mandatory provisions of law. Only certain aspects of it are subject to certain legal acts and they mostly contain directives addressed to the entities organizing and operating stock exchanges. In Poland, currently only the Warsaw Stock Exchange S.A. provides such services pertaining to the trading in shares. The stock exchange is organized into two separate markets: The Main Market, which is essentially the regulated market within the Directive 2014/65/EU ${ }^{36}$ definitions, and the New Connect, which is a multilateral trading platform. ${ }^{37}$ Both markets have their own rules which provide detailed procedures for attaining the status of the company listed on it. Due to this reason and absence of other organized trading venues for shares in Poland, from a practical point of view only these regulations should be taken into account. Besides, it should be noted that a Polish joint-stock company may be listed on foreign stock exchanges, provided that it complies with their particular regulations. ${ }^{38}$ Foreign listing of a Polish company is not covered by this article.

The decision to classify a given joint-stock company as a listed company is, as a result, mostly in the hands of the Warsaw Stock Exchange. To be more precise, a company which fulfills the criteria expressed in its rules, needs subsequently to submit a motion for admission to trading which is filed within the WSE Management Board. If it approves such a motion, then it indicates the day beginning with the applicant becoming a listed company. Apparently, now it is the role of a private entity to determine whether a company should be subject to stricter public law regulations concerning its operation or not. Although such a motion must be previously accompanied by the approval of a prospectus regarding the admission of shares to trading on the regulated market granted by the Polish Financial Supervision Authority, the final decision lies within the WSE Management Board, as it is not bound by the approval of the mentioned prospectus.

The elimination of temporary public company status, attained at the moment of dematerialization of at least one share, means that joint-stock companies are becoming subject to duties set forth in the APO at a later stage, and do not have to apply public-regime rules of the CCC immediately following the moment of dematerialization of its shares.

${ }^{36}$ Directive 2014/65/EU of the European Parliament and of the Council of 15 May 2014 on markets in financial instruments and amending Directive 2002/92/EC and Directive 2011/61/EU.

${ }^{37}$ See Warsaw Stock Exchange's website: https://www.gpw.pl/en-home (accessed: 12.06.2019).

${ }^{38}$ Either in form of foreign primary listing or dual listing. 
This amendment should be positively assessed. It eliminated all the above presented issues related to terms of listed and public companies and essentially turns them into synonyms. Also, such an understanding of a public company is consistent with foreign legal systems and, surprisingly, with the previously applicable law prior to the entry into force of the APO. Under Article 4(9) of the Act on Public Trading in Securities, ${ }^{39}$ a public company was defined as a company where at least one share from one series was admitted to public trading. Apparently, this definition stood more in line with trading practice than the currently binding definition under the non-amended APO. These changes are also beneficial from the perspective of non-public joint-stock companies which finally may decide freely to dematerialize their shares, in whole or in part, ${ }^{40}$ which does not automatically result in turning them into a public company. Due to these changes especially, gathering of capital by start-ups or issuers through equity-based crowdfunding may be facilitated as traditional issuance of documentary shares is deemed to be costly and ineffective. ${ }^{41}$

\section{Conclusions}

The conducted analysis proves that the notion of a public company was wrongly constructed in Polish commercial law. Basically, de lega lata it is classified as one of many subtypes of joint-stock company, next to banking, insurance, sport, etc. specialist forms of joint-stock company. In other words, if a company wishes to introduce its shares into trading on the organized market, it must be organized in a form of joint-stock company as no other types of commercial company may become a listed company. However, such an assumption made by the legislator is wrong and departs far from the nature of a public company.

Essentially, a public joint-stock company is the pure capital company type. It possesses all the attributes which are in theory associated with a model jointstock company, such as professional management, equality of its shareholders, absence of any privileges granted to shareholders, non-restricted transferability of shares, implemented rules on corporate governance, massive structure of shareholding, etc. It does not implement any personal features typical for partnerships, which are mostly based on trust relations between their partners, instead of their capital contributions. Unfortunately, the Polish legislator decided otherwise and established within the frames of the CCC the private variant of

${ }^{39}$ Act dated 21 August 1997 — on Public Trading in Securities (Journal of Laws 1997 no. 118, item 754 , as amended).

${ }^{40}$ Provided the Amendment to the CCC will not enter into force which will put on duty to mandatory dematerialize all shares. Besides, it should be noted that Amendment to the APO is scheduled to enter into force earlier than Amendment to the CCC, therefore possibility herein mentioned will exist at least temporally.

${ }^{41}$ T. Sójka, op. cit., pp. 16-17. 
a joint-stock company as a model joint-stock company. In practice such companies are typically used as a vehicle to run a family business in the form of corporation or serve surprisingly as a more flexible investment vehicle than a limited liability company. Consequently, they are not intended to become a listed company as their major shareholders would lose control over such an entity. De lege ferenda the CCC should be reworked in this regard.

Notably, the proposed amendments to the APO and the CCC should be considered as first steps to redefine the model regulation of a joint-stock company in the CCC. In the longer perspective, the private variant of a joint-stock company should be removed from the CCC and be replaced with the public company model entirely.

\section{References}

Akimenkow A., "Spółka giełdowa a spółka publiczna — podstawy normatywne dystynkcji oraz koncepcje reformy nominałowej kapitału zakładowego," Przeglad Prawa Handlowego 2018, no. 9.

Chłopecki A., "Regulacje spółki publicznej a kodeks spółek handlowych," Przegląd Prawa Handlowego 2015, no. 4.

Famirski A., [in:] Ustawa o obligacjach. Komentarz, ed. M. Wierzbowski, Warszawa 2019.

Frąckowiak J., Kidyba A., Kidyba S., Popiołek W., Spyra M., [in:] System Prawa Handlowego, vol. 2B. Prawo spótek handlowych ed. A. Szumański, Warszawa 2019.

Grześkow M., "Rozważania nad kształtem prostej spółkiakcyjnej(PSA),"Internetowy Przeglad Prawniczy TBSP UJ 2017, no. 10, http://www.tbsp.wpia.uj.edu.pl/documents/4137545/140073332/ IPP_10_2017.pdf/1af5e322-ebf0-4478-baae-0a6aded86272.

Kappes A., "Prosta spółka akcyjna - czy rzeczywiście prosta i czy potrzebna? Uwagi do projektu nowelizacji Kodeksu spółek handlowych, wprowadzającego prostą spółkę akcyjną (projektowane art. $300^{1-300^{121}}$ k.s.h.)," Przegląd Prawa Handlowego 2018, no. 5.

Michalski M., [in:] Ustawa o obrocie instrumentami finansowymi. Komentarz, eds. M. Wierzbowski, L. Sobolewski, P. Wajda, Warszawa 2018.

Michalski M., "O pojęciu i zakresie regulacji spółki publicznej," Przegląd Prawa Handlowego 2008, no. 1.

Opalski A., [in:] Kodeks spótek handlowych, vol. 3A. Spółka akcyjna. Komentarz do art. 301-392, ed. A. Opalski, Warszawa 2016.

Oplustil K., Instrumenty nadzoru korporacyjnego (corporate governance) w spótce akcyjnej, Warszawa 2010.

Regucki T., Mechanizmy zwiększające kontrolę (control enhancing mechanisms) w polskich spótkach akcyjnych. Analiza prawno-ekonomiczna, Warszawa 2018.

Romanowski M., "W sprawie pojęcia i natury spółki publicznej," Przegląd Prawa Handlowego 2009, no. 3 .

Sołtysiński S., Moskwa P., [in:] System Prawa Prywatnego, vol. 17A, ed. S. Sołtysiński, Warszawa 2015.

Sójka T., "O potrzebie zmian unormowań niepublicznych spółek kapitałowych — uwagi na kanwie projektu przepisów o prostej spółce akcyjnej," Przeglad Prawa Handlowego 2018, no. 9.

Spyra M., [in:] System Prawa Handlowego, vol. 4. Prawo instrumentów finansowych, ed. M. Stec, Warszawa 2016. 
Szajkowski A., [in:] System Prawa Prywatnego, vol. 16, ed. A. Szajkowski, Warszawa 2016.

Szumański A., [in:] Kodeks spótek handlowych. Komentarz do art. 1-150, vol. 1, eds. S. Sołtysiński, A. Szajkowski, A. Szumański, Warszawa 2012.

Wiórek P.M., "O braku potrzeby wprowadzenia prostej spółki akcyjnej (PSA) z perspektywy prawnoporównaczej," Przegląd Prawa Handlowego 2018, no. 5.

Włodyka S., Szumański A., [in:] System Prawa Handlowego, vol. 2A. Prawo spótek handlowych, ed. A. Szumański, Warszawa 2019. 